\title{
The Self-Purification Ability in the Rivers of Banjarmasin, Indonesia
}

\author{
Tien Zubaidah ${ }^{1,2^{*}}$, Nieke Karnaningroem ${ }^{1}$, Agus Slamet ${ }^{1}$ \\ 1 Environmental Engineering Department, Faculty of Civil, Environmental, and Geo-Engineering, Institut \\ Teknologi Sepuluh Nopember, ITS Str. Sukolilo, Surabaya 60111, Indonesia \\ 2 Enviromental Department, Banjarmasin Health Polytechnic of Ministry of Health, Mistar Cokrokusumo Str 1A, \\ Banjar Baru 70714, Indonesia \\ * Corresponding author's e-mail: arrasyid.hanif@gmail.com
}

\begin{abstract}
The self-purification capacity of river water is an essential indicator for a healthy river. Various organic and inorganic pollutants, both from point sources and nonpoint sources, in most streams in Banjarmasin were beyond the river self-purification capacity, which caused a decrease in the river water quality. This study attempted to identify the river water pollution distribution in the city of Banjarmasin and determined the self-purification points. We used the purposive sampling technique to carry out river water sampling, with criteria for pollutant sources and distance of pollution taken into consideration. By using the trend analysis techniques, we analyzed the parameters concentration to relate it to the range of pollution so that we were able to identify the pollution distribution and determine the self-purification distances. The results indicated that the self-purification process could take place on the river flow in of Banjarmasin even though it did not reach the clean water zone. The river in Banjarmasin requires a longer purification distance so that the self-purification process can run correctly.
\end{abstract}

Keywords: self-purification, river water pollution, Banjarmasin river

\section{INTRODUCTION}

Naturally, the river can recover the pollutant load within certain limits. The self-recovery capabilities of each stream are not the same and depend on the characteristics of each river, including flow velocity, water discharge volume and initial waste content in the river water. The habits of riverside communities also resulted in increased polluted loads to the river waters [Effendi, 2016; Müller et al., 2008]. If the pollutant load is higher than the water assimilation capacity, indicated by the high pollutant concentration compared to the standard quality threshold, then it will have an impact on the decreasing quality of river water.

Our previous research found that the rivers of Banjarmasin were categorized as heavily polluted, with domestic and industrial activities identified as significant pollution sources [Zubaidah et al., 2018\}. The disposal of domestic, mining, plantation, agricultural and industrial wastes in Banjarmasin city was carried out without suf- ficient treatment, causing a higher potential risk to the rivers in the city. This condition indeed requires an in-depth study that focuses on the water quality pollution and the distribution of self-purification points along the river of Banjarmasin city.

\section{MATERIAL AND METHODS}

We used the field survey method and laboratory test to identify the watershed pollution distribution points and the self-purification process of ongoing pollution. We also made measurements and records in the exact spot and distance of every pollution process points, since the self-purification process in river flow was divided into three pollution process-based zones, i.e., clean water, degradation, and recovery zone. The measurements and records were performed to obtain representative pollution distribution and characteristics representation, as well as the exact distance of the self-purification process along the river 
flow. By using purposive sampling technique, as well as pollutant point of source and their intervals as its criteria, the location sampling points were presented in Figure 1.

We used the trend analysis techniques to identify distribution and indicate the self-purification points with diagrams and charts. Displaying them will provide a representative condition of the water quality concentration of each examined parameters and its relationship to the polluted river distances.

\section{RESULT AND DISCUSSION}

\section{River water's physical quality in Banjarmasin city}

a) Temperature

Various factors such as seasons, latitude, sea level altitude, air circulation, cloud shade, and water flow and depths can affect the temperature of water bodies. The changes in temperature itself also affected the physical, chemical, as well as biological process on the water bodies [Morrill et al., 2005]. The results on the river water temperature measurement in Banjarmasin can be seen in table 1 as follow.

Table 1 shows that the flow conditions of Banjarmasin's river did not experience high-temperature change intensity (from 28.6 to $30.2{ }^{\circ} \mathrm{C}$ ).
At the $1^{\text {st }}$ sample point, the water condition was at the lowest temperature because it did not experience high volume waste infiltration, while at the pollution starting point ( $2^{\text {nd }}$ sample point) the river water temperature increased up to $29.6^{\circ} \mathrm{C}$. The temperature continued to rise until the $4^{\text {th }}$ point where liquid waste was mixed perfectly, and the river water temperature reached $29.80^{\circ} \mathrm{C}$. However, the highest temperature occurred at the $5^{\text {th }}$ and $6^{\text {th }}$ sample points (up $30.2^{\circ} \mathrm{C}$ ) due to the full opened sample point locations and greater sun exposure on the river water surface.

\section{b) Total Suspended Solid (TSS)}

Total Suspended Solid (TSS) defined as the dry sludge weight ( $\mathrm{mg} /$ liter) contained in wastewater after being filtered with a 0.45 -micron membrane [Kaul, 2005]. The TSS measurement results on the locations of sample points are shown in Table 2.

Table 2 shows the TSS concentration distribution fluctuation pattern, where the concentration increase starts at 2 points $(25 \mathrm{mg} / \mathrm{L})$ and the highest value occurs at 3 point $(30 \mathrm{mg} / \mathrm{L})$. This condition was caused by the inclusion of additional pollutant load from the tributaries that exist between the river segments, which then lead to the main river flowing at the $3^{\text {rd }}$ sample point. These conditions indicate that the TSS concentrations from the river water polluted at $1^{\text {st }}, 2^{\text {nd }}$, and $3^{\text {rd }}$ sample points did not show any significant decrease.

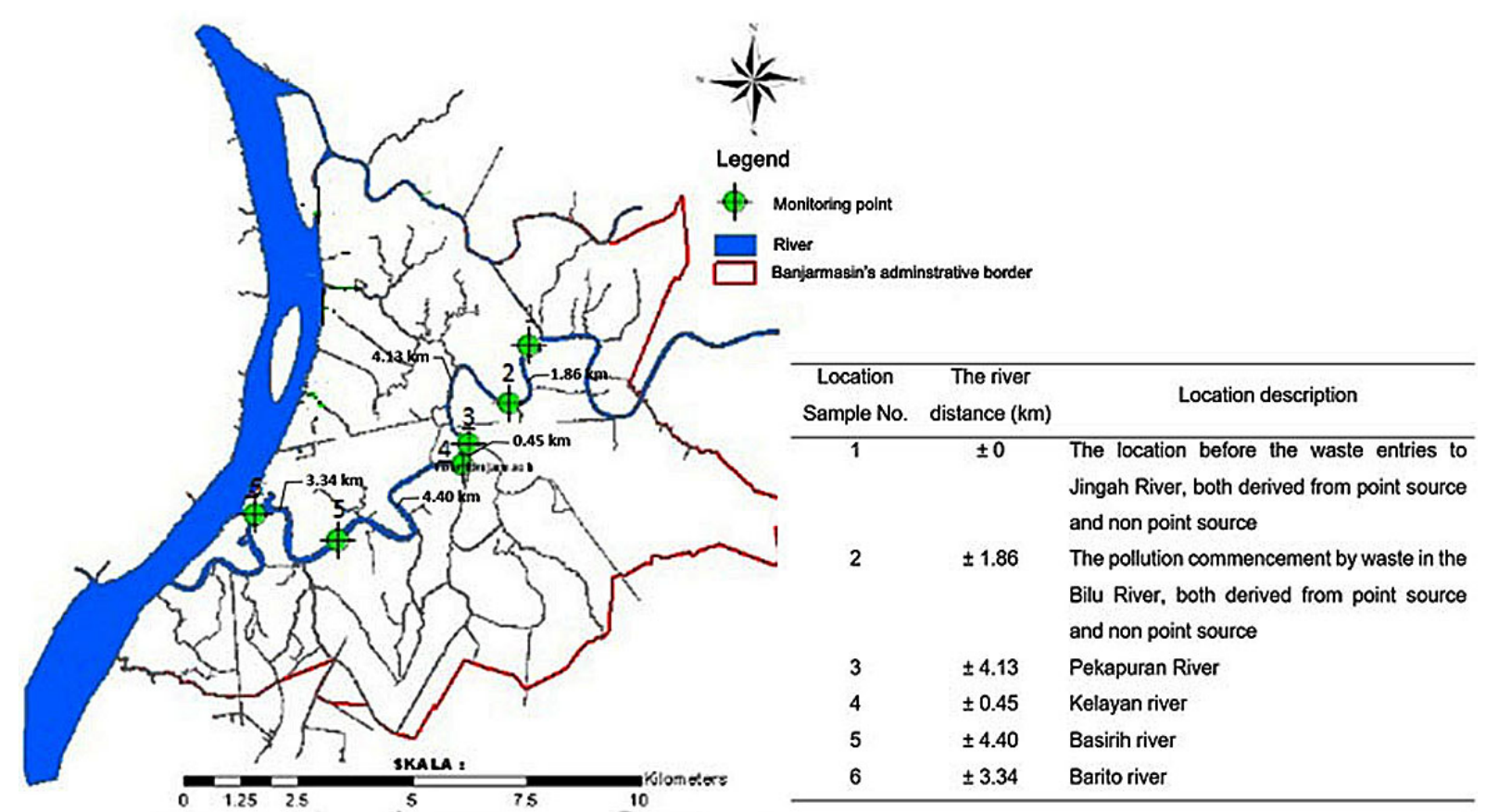

Figure 1. The Banjarmasin river water quality sampling points location 
Table 1. The river water temperature condition in Banjarmasin city

\begin{tabular}{|c|c|c|}
\hline Sample points \# & $\begin{array}{c}\text { The river } \\
\text { distances }(\mathrm{km})\end{array}$ & Temperature $\left({ }^{\circ} \mathrm{C}\right)$ \\
\hline 1 & \pm 0.00 & 28.60 \\
\hline 2 & +1.86 & 29.60 \\
\hline 3 & +5.99 & 29.90 \\
\hline 4 & +6.44 & 29.80 \\
\hline 5 & +10.84 & 30.00 \\
\hline 6 & +14.80 & 30.20 \\
\hline
\end{tabular}

\section{River water's chemical quality in Banjarmasin}

\section{a) Acidity}

The ideal $\mathrm{pH}$ level allows the biological life in the water to flourish correctly, and neutral acidity ( $\mathrm{pH} 7$ ) is considered a perfect condition for wastewater (Bagchi, 2013). Most aquatic organisms are sensitive to the changes in $\mathrm{pH}$ and prefer the values of $\mathrm{pH}$ from 7 to 8.5 (Dallas and Jha, 2015). Laboratory test results of $\mathrm{pH}$ levels at the sample points are shown in table 3 below.

The $\mathrm{pH}$ concentration in the rivers of Banjarmasin, both before and after pollutants infiltration, did not show a fluctuating pattern. Although the $\mathrm{pH}$ level increased at the $2^{\text {nd }}$ sample point $(\mathrm{pH} 7.73)$ due to the of pollutant loads entry, at the $3^{\text {rd }}, 4^{\text {th }}$ and $5^{\text {th }}$ sample point, the $\mathrm{pH}$ value dropped and stagnated at 6.92. The $\mathrm{pH}$ range between 6.86 and 7.73 , it indicates that polluted river still allows microorganisms to carry out their decomposing pollutant loads functions to survive.

\section{b) Dissolved Oxygen}

The oxygen contained in water (milligrams per liter) is called Dissolved Oxygen (DO) and is usually used as a sign of pollution degree in water bodies (Kaul, 2005). Table 4 shows the dissolved oxygen (DO) levels measurements results in the rivers of Banjarmasin

Table 3. The $\mathrm{pH}$ concentration in the rivers of Banjarmasin

\begin{tabular}{|c|c|c|}
\hline Sample points \# & $\begin{array}{c}\text { The river } \\
\text { distances }(\mathrm{km})\end{array}$ & $\mathrm{pH}$ \\
\hline 1 & \pm 0.00 & 6.86 \\
\hline 2 & +1.86 & 7.73 \\
\hline 3 & +5.99 & 6.92 \\
\hline 4 & +6.44 & 6.92 \\
\hline 5 & +10.84 & 6.92 \\
\hline 6 & +14.80 & 6.76 \\
\hline
\end{tabular}

Table 2. The TSS concentration in the rivers of Banjarmasin

\begin{tabular}{|c|c|c|}
\hline Sample points \# & $\begin{array}{c}\text { The river } \\
\text { distances }(\mathrm{km})\end{array}$ & TSS $(\mathrm{mg} / \mathrm{L})$ \\
\hline 1 & \pm 0.00 & 24.00 \\
\hline 2 & +1.86 & 25.00 \\
\hline 3 & +5.99 & 30.00 \\
\hline 4 & +6.44 & 8.00 \\
\hline 5 & +10.84 & $<0.01$ \\
\hline 6 & +14.80 & 5.00 \\
\hline
\end{tabular}

The sample starting point showed the DO value of $5.39 \mathrm{mg} / \mathrm{L}$ (before infiltration of pollutant loads) and slowly rises to the $3^{\text {rd }}$ sample point which reached $5.80 \mathrm{mg} / \mathrm{L}$. The increase indicated the opportunity for water bodies to carry out reoxygenation to increase their dissolved oxygen levels. However, at $4^{\text {th }}, 5^{\text {th }}$ and $6^{\text {th }}$ sample points, the DO concentration was degraded until it reached $4.10 \mathrm{mg} / \mathrm{L}$, caused by the diffuse mixture of pollutant loads that cause the dissolved oxygen concentration to decrease.

Another waste load infiltration due to trade and industrial activities was observed between the $4^{\text {th }}$ and $6^{\text {th }}$ sample points, resulting in the volume of wastewater that should be reduced However, it actually becomes concentrated again and the diffusion process of oxygen into the water bodies becomes obstructed.

c) Biochemical Oxygen Demand (BOD)

Biochemical Oxygen Demand (BOD) shows the amount of dissolved oxygen required by living organisms to break down or oxidize the waste materials in water (Gooch, 2007). Table 5 below shows the results of BOD levels measurements in the rivers of Banjarmasin

The distribution of BOD concentration values fluctuated, the $1^{\text {st }}, 2^{\text {nd }}$ and $3^{\text {rd }}$ sample points experienced an increase from 10.65 $\mathrm{mg} / \mathrm{L}$ to $19.52 \mathrm{mg} / \mathrm{L}$ too, then decreased again in the $4^{\text {th }}$ and $6^{\text {th }}$ sample points. The increase

Table 4. Dissolved Oxygen levels in the rivers of Banjarmasin

\begin{tabular}{|c|c|c|}
\hline Sample points \# & $\begin{array}{c}\text { The river } \\
\text { distances }(\mathrm{km})\end{array}$ & $\mathrm{DO}(\mathrm{mg} / \mathrm{L})$ \\
\hline 1 & \pm 0.00 & 5.39 \\
\hline 2 & +1.86 & 5.50 \\
\hline 3 & +5.99 & 5.80 \\
\hline 4 & +6.44 & 4.36 \\
\hline 5 & +10.84 & 4.18 \\
\hline 6 & +14.80 & 4.10 \\
\hline
\end{tabular}


Table 5. Biochemical oxygen demand levels in the rivers of Banjarmasin

\begin{tabular}{|c|c|c|}
\hline Sample points \# & $\begin{array}{c}\text { The river } \\
\text { distances }(\mathrm{km})\end{array}$ & BOD $(\mathrm{mg} / \mathrm{L})$ \\
\hline 1 & \pm 0.00 & 10.65 \\
\hline 2 & +1.86 & 15.16 \\
\hline 3 & +5.99 & 19.52 \\
\hline 4 & +6.44 & 17.31 \\
\hline 5 & +10.84 & 17.74 \\
\hline 6 & +14.80 & 19.52 \\
\hline
\end{tabular}

in BOD occurs due to an increase in the microorganism reaction to the organic materials from wastewater that infiltrated the river flow. This condition also indicates that the liquid waste was fully mixed so that the wastewater concentration was high, and decomposition activity, both aerobic and anaerobic, was high. The decrease in the pollutants concentration also demonstrated a well-oxidized process that indicated increased oxygen levels in the river segment between points 4 and 5 . However, at the $6^{\text {th }}$ sample point, the BOD concentration increased again, which was caused by new waste load infiltration from the tributaries located not far from the $5^{\text {th }}$ sample point. This condition resulted in a repeated increase in the reaction of microorganisms at the $5^{\text {th }}$ sample point and became the main reason for the low DO levels at the $5^{\text {th }}$ and $6^{\text {th }}$ sample points.

d) Chemical Oxygen Demand (COD)

Chemical Oxygen Demand (COD) describes the total amount of oxygen needed to oxidize organic material chemically, both biodegradable and non-biodegradable, to $\mathrm{CO}^{2}$ and $\mathrm{H}_{2} \mathrm{O}$ (Lewis, 2016). Table 6 presents the results of COD levels measurements in the rivers of Banjarmasin.

Table 6 showed that since the beginning of waste pollution location, in both point and non-

Table 6. Chemical oxygen demand levels in the rivers of Banjarmasin

\begin{tabular}{|c|c|c|}
\hline Sample points \# & $\begin{array}{c}\text { The river } \\
\text { distances }(\mathrm{km})\end{array}$ & COD $(\mathrm{mg} / \mathrm{L})$ \\
\hline 1 & \pm 0.00 & 26.96 \\
\hline 2 & +1.86 & 38.35 \\
\hline 3 & +5.99 & 49.39 \\
\hline 4 & +6.44 & 43.79 \\
\hline 5 & +10.84 & 44.89 \\
\hline 6 & +14.80 & 49.39 \\
\hline
\end{tabular}

point sources, the waste contamination degree was in high concentration so that the biological decomposition process was not able to reduce the waste load volume infiltrated the water sufficiently. In the end, the chemical decomposition process started to actively help to break down and decompose the pollutant loads that infiltrated the river water flow.

In the $1^{\text {st }}$ sample point, with a COD value of $26.96 \mathrm{mg} / \mathrm{L}$, the location was already categorized as a polluted area. The highest COD concentration occurs in the $3^{\text {rd }}$ sample point $3(49.39 \mathrm{mg} / \mathrm{L})$ which indicates a complete mixing of industrial waste load that infiltrated the river flow. Industrial waste infiltration from the tributaries in the river segments between the $4^{\text {th }}$ and $5^{\text {th }}$ sample points contributes to the COD concentration increment at the $5^{\text {th }}$ sample point

\section{Self-Purification Process in the Rivers of Banjarmasin}

The self-purification process can be determined through several stages formed in the river water recovery zones.

The self-purification identification process against the polluted river water in Banjarmasin was carried out using the trend analysis, with tables and line graphs that connected the value of element concentrations with the river distance. In this way, the self-purification distance that takes place in the river water flow can be identified precisely. We used three chemical parameters that represent the self-purification process, including $\mathrm{DO}, \mathrm{BOD}$, and $\mathrm{COD}$, to illustrate the waste contamination intensity that pollutes the river water in the study area. The overall trend of the three chemical parameters in polluted river water is shown in Figure 2.

On the basis of the analysis pertaining to the three chemical parameters, the river selfpurification in the study area can occur, indicated with the BOD and COD concentrations decreased at the $4^{\text {th }}$ sample point. However, with the DO levels that did not increase up to the last location (sample point 6), the river self-purification process due to waste pollution, both from the point source and non-point source, has not yet reached the clean water zone, which is the last phase of the process. The river selfpurification process zones distribution in the study area was shown in Figure 3. 


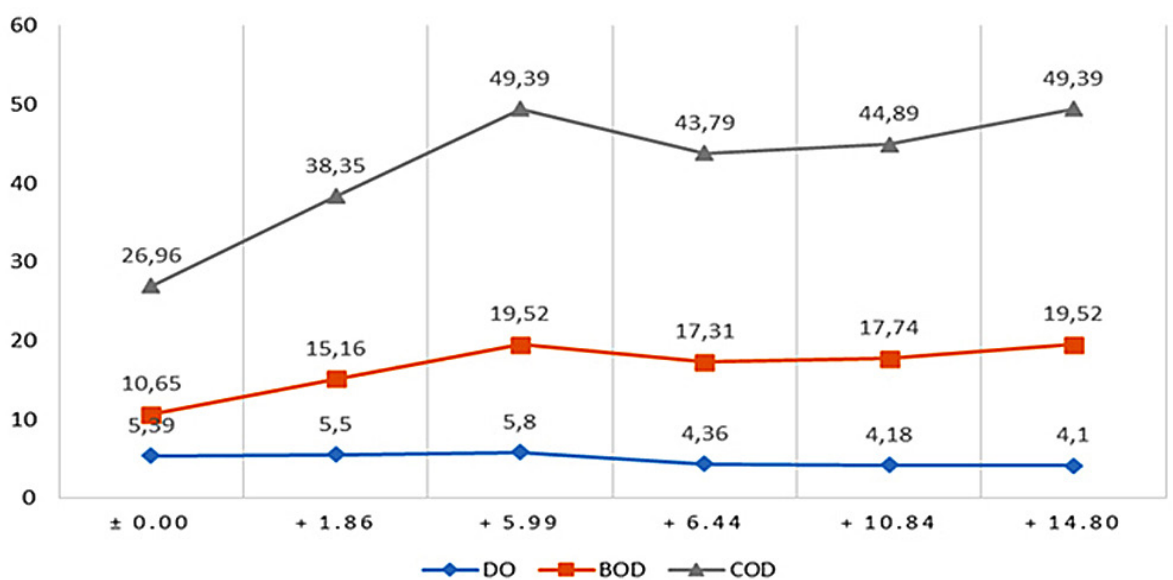

Figure 2. The DO, BOD, and COD concentration trend against the river distance

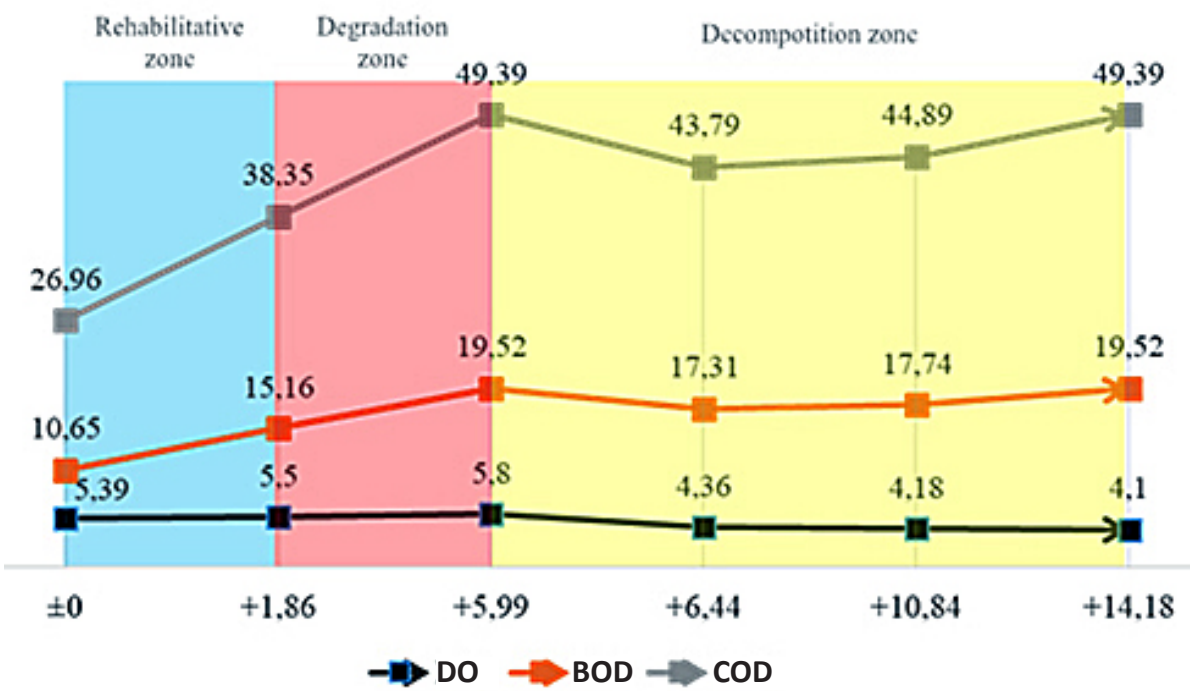

Figure 3. Distribution of the river self-purification process zones by distances

\section{CONCLUSION}

Distribution of river water pollution in the study area showed a fluctuating pattern trend. The waste contamination degree tends to increase in the $4^{\text {th }}$ and $6^{\text {th }}$ sample points; for DO as a supporting factor, the self-purification process tends to decrease until the last sample point.

Overall, the self-purification process on polluted rivers in the city of Banjarmasin was able to take place, but based on the phase, the selfpurification process at the research location did not reach the last zone, the clean water zone. This condition indicated that the Banjarmasin's river flow requires a longer distance to achieve the perfect phase of the self-purification process, provided there is no more new waste infiltration from the stream of tributaries in the next location.

\section{REFERENCES}

1. Bagchi, B., 2013. The $\mathrm{pH}$ of water. In: Water in Biological and Chemical Processes: From Structure and Dynamics to Function, Cambridge Molecular Science. Cambridge University Press, Cambridge, pp. 71-78.

2. Dallas, L.J., Jha, A.N., 2015. Applications of biological tools or biomarkers in aquatic biota: A case study of the Tamar estuary, South West England. Marine Pollution Bulletin, The English Channel and it's catchments: Status and Responses to Contaminants 95, 618-633.

3. Effendi, H., 2016. River Water Quality Preliminary Rapid Assessment Using Pollution Index. Procedia Environmental Sciences, The 2nd International Symposium on LAPAN-IPB Satellite (LISAT) for Food Security and Environmental Monitoring 33, 562-567.

4. Gooch, J.W., 2007. Biochemical Oxygen Demand 
(BOD). In: Encyclopedic Dictionary of Polymers. Springer, New York, NY, pp. 108-108.

5. Kaul, S.N., 2005. Wastewater Management: With Special Reference to Tanneries. Discovery Publishing House.

6. Lewis, R.A., 2016. Hawley's Condensed Chemical Dictionary. John Wiley \& Sons.

7. Morrill, J.C., Bales, R.C., Conklin, M.H., 2005. Estimating Stream Temperature from Air Temperature: Implications for Future Water Quality. Jour- nal of Environmental Engineering 131, 139-146.

8. Müller, B., Berg, M., Yao, Z.P., Zhang, X.F., Wang, D., Pfluger, A., 2008. How polluted is the Yangtze river? Water quality downstream from the Three Gorges Dam. Science of The Total Environment 402, 232-247.

9. Zubaidah, T., Karnaningroem, N., Slamet, A., 2018. K-Means Method for Clustering Water Quality Status on The Rivers of Banjarmasin, Indonesia. ARPN Journal of Engineering and Applied Sciences 13, 6. 